\section{Response of Peach Seedlings to Root- zone Temperature and Root-applied Growth Regulators}

\author{
M. Tagliavini ${ }^{1}$ and N.E. Looney \\ Agriculture Canada, Research Station, Summerland, B.C. VOH 1ZO, \\ Canada
}

Additional index words. Prunus persica, gibberellic acid, paclobutrazol, hydroponics, dry weight partitioning, gibberellin physiology, video root system analysis

Abstract. Root and shoot growth of peach seedlings was strongly suppressed when the roots were held at 8 to $10 \mathrm{C}$. Shoot and root dry weights and root volume increased linearly with increasing root-zone temperature (RZT) to $22 \mathrm{C}$. $\mathrm{GA}_{3}$ at $5.7 \mu \mathrm{M}(2 \mathrm{ppm})$ added to the aerated full nutrient solution reversed the effect of low RZT on shoot elongation but inhibited root growth at all RZTs. Paclobutrazol (PBZ) $\left(6.8 \times 1^{-3}\right.$ нм) (2 ppb) inhibited shoot elongation at all RZTs and shoot dry weight at 16 and 22C. However, PBZ had no effect on root dry weight accumulation at any RZT. The shoot growth-promoting effect of $\mathbf{G A}_{3}$, relative to control plants, disappeared at higher RZTs, but $\mathrm{GA}_{3}$ reversed the growth-inhibiting effect of PBZ at all RZTs. PBZ increased mean root diameter at all RZTs and significantly increased root volume at $22 \mathrm{C}$. These results show that growth of peach seedlings is profoundly influenced by a cool rootzone environment. The plant growth regulator effects suggest that seedling roots play an important role in whole-plant gibberellin physiology. Some possible implications for fruit production are discussed. Chemical names used: gibberellic acid $\left(G_{3}\right) ; \beta-[(4-$ chlorophenyl)methyl]- $\alpha$-(1,1-dimethylethyl)-1H-1,2,4-triazole-1-ethanol(paclobutrazol,PBZ).

Container production of rootstock liners and finished trees is an increasingly attractive option for nurseries and orchardists interested in producing planting stock of deciduous fruit trees (Tattini et al., 1988). These systems, usually involving a relatively inert rooting medium and the introduction of mineral nutrients with the irrigation water (fertigation), present interesting new opportunities for the efficient application of plant growth-regulating chemicals (PGRs) via the root system. For example, effective soil solution concentrations of PBZ, a potent plant growth inhibitor, are several orders of mag-

Received for publication 14 May 1990. Contribution no. 783. The valuable assistance of Lazlo Veto in preparing and analyzing the digitized video images is gratefully acknowledged. The cost of publishing this paper was defrayed in part by the payment of page charges. Under postal regulations, this paper therefore must be hereby marked advertisement solely to indicate this fact.

'Present address: Istituto di Coltivazioni Arboree, Via F. Re 6, 40126 Bologna, Italy. nitude lower than what is required in a foliar spray,

However, much is yet to be learned about the potential risks and benefits of root-applied growth regulators, the minimum soil solution concentrations resulting in biological activity, and the many factors influencing their efficacy. It is known that root-applied gibberellins are absorbed and transported throughout the plant (Davies and Rappaport, 1975) and that they promote shoot elongation of both herbaceous (Anderson et al., 1988; Arteca et al., 1985; Jackson and Field, 1972) and woody perennial plants (Heidmann, 1982; Little and Loach, 1975). It is also known that triazol growth inhibitors (e.g., PBZ and uniconazole) have the opposite effect on shoot growth (Early and Martin, 1988; Erez, 1986). However, there is only indirect evidence that root-zone temperature can influence these PGR effects (Lavender et al., 1973; Menhenett and Waring, 1975).

The objectives of the experiments described herein were to determine the responsiveness of peach seedlings to a range of root-zone temperatures and to observe the concomitant response to low levels of $\mathrm{GA}_{3}$ and PBZ, alone and in combination, in the nutrient solution.

In each of two experiments, 'Rutger's Red Leaf' peach seeds were germinated and grown in vermiculite to an average shoot length of 10 to $12 \mathrm{~cm}$. Carefully washed seedlings were weighed and transferred to 1-liter lined containers containing a complete Long Ashton nutrient solution (Hewitt, 1966). This solution was aerated continuously and renewed weekly. Both experiments were carried out in controlled-environment growth rooms (Conviron Systems, Winnepeg, Man., Canada) equipped with circulating water baths to provide up to three root-zone temperature (RZT) regimes per room. The aerial portion of each seedling received a $16-\mathrm{h}$ photoperiod, a thermoperiod of $24 \mathrm{C}$ days/18C nights, and illuminance of $156 \mu \mathrm{mol} \cdot \mathrm{s}^{-1} \cdot \mathrm{m}^{-2}$. Day and night relative humidity was maintained at $75 \%$.

In Expt. 1, the following treatments were applied to each of four seedlings held at RZTs of either 8 or $24 \mathrm{C}$ : a) no $\mathrm{GA}_{3}$ or $\mathrm{PBZ}$; b) $2.8 \mu \mathrm{M}(1 \mathrm{ppm}) \mathrm{GA}_{3}$ in the aerated nutrient solution; c) $3.4 \times 10^{-3} \mu \mathrm{M}(1 \mathrm{ppb}) \mathrm{PBZ}$ in the nutrient solution; and d) the combination of $\mathrm{GA}_{3}+\mathrm{PBZ}$. Experiment duration was 14 days.

Experiment 2 was expanded to two growth rooms to provide additional replication (three seedlings per PGR/RZT in each room). Three RZT regimes were tested $(10,16$, and $22 C)$, and the $\mathrm{GA}_{3}$ and $\mathrm{PBZ}$ concentrations in the rooting medium were double those used in Expt. 1. Experiment duration was 3 weeks.

Weekly measurements were made of shoot length, root volume (by displacement), and total fresh weight. For Expt. 2, entire root systems were examined 20 days after application of the PGRs by analysis of a digitized video image acquired with a Dage-68 Series MK II video camera. A combination of transmitted and reflected illumination was used to obtain high-quality full-gray scale images. Each image was stored in a TracorNorthern 502 computer (Middleton, Wis.) in a frame of $512 \times 480$ pixels $(245,760$ individual picture elements), each having a gray level from 0 to 255 . These digitized images were then processed by the Tracer-Northern image processing system to obtain information about total root surface area and average root diameter. 
Table 1. Effect of root-zone temperature (RZT) and plant growth regulator (PGR) treatments on shoot elongation and final root volume of peach seedlings (Expt. 1).

\begin{tabular}{lccccc}
\hline \multirow{2}{*}{ PGR } & \multicolumn{2}{c}{ Shoot growth $(\mathrm{mm})$} & & \multicolumn{2}{c}{ Final root vol $(\mathrm{ml})$} \\
\cline { 2 - 3 } \cline { 5 - 6 } & $8 \mathrm{C}$ & $24 \mathrm{C}$ & & $8 \mathrm{C}$ & $24 \mathrm{C}$ \\
\hline None & $112 \mathrm{ab}^{z}$ & $176 \mathrm{a}$ & & $1.4 \mathrm{a}$ & $3.6 \mathrm{ab}$ \\
$\mathrm{GA}_{3}(1 \mathrm{ppm})$ & $139 \mathrm{a}$ & $169 \mathrm{ab}$ & & $0.9 \mathrm{c}$ & $2.0 \mathrm{~b}$ \\
$\mathrm{PBZ}(1 \mathrm{ppb})$ & $89 \mathrm{~b}$ & $142 \mathrm{c}$ & & $1.0 \mathrm{bc}$ & $4.7 \mathrm{a}$ \\
$\mathrm{GA}_{3}+\mathrm{PBZ}$ & $135 \mathrm{a}$ & $152 \mathrm{bc}$ & & $1.2 \mathrm{ab}$ & $2.4 \mathrm{~b}$ \\
& \multicolumn{2}{c}{ RZT $^{* * *}$} & & \multicolumn{2}{c}{ RZT*** } \\
& \multicolumn{2}{c}{ RZT $\times$ PGR $^{* *}$} \\
\hline
\end{tabular}

${ }^{2}$ Mean separation within columns by Duncan's multiple range test, $P=0.05$.

$*, * * * * *$ Significant at $P=0.05,0.01$, or 0.001 , respectively.

Table 2. Indicators of the influence of root-zone temperature on shoot and root growth of peach seedlings (Expt. 2).

\begin{tabular}{|c|c|c|c|c|}
\hline \multirow[b]{2}{*}{ Criterion } & \multicolumn{3}{|c|}{ Root-zone temp $\left({ }^{\circ} \mathrm{C}\right)$} & \multirow{2}{*}{$\begin{array}{c}\text { Significance of } \\
\text { linear regression }\end{array}$} \\
\hline & 10 & 16 & 22 & \\
\hline Final shoot length (mm) & 269 & 326 & 313 & NS \\
\hline Shoot dry wt (mg) & 660 & 1490 & 1710 & $* *$ \\
\hline Final root vol (ml) & 1.68 & 3.43 & 3.73 & $*$ \\
\hline Root surface area $\left(\mathrm{cm}^{2}\right)$ & 146 & 235 & 353 & $* *$ \\
\hline Root dry wt $(\mathrm{mg})$ & 160 & 290 & 350 & * \\
\hline Shoot : root dry wt ratio & 4.4 & 5.0 & 5.1 & $*$ \\
\hline
\end{tabular}

NS,*,**Not significant or significant at $P=0.05$ or 0.01 , respectively.

Table 3. Effects of root-zone temperature (RZT) and plant growth regulator (PGR) treatments on shoot length increase of peach seedlings during two growth periods (Expt. 2).

\begin{tabular}{|c|c|c|c|c|c|c|}
\hline \multirow[b]{3}{*}{ PGR } & \multicolumn{6}{|c|}{ Shoot length increase $(\mathrm{mm})$} \\
\hline & \multicolumn{3}{|c|}{ After 14 days treatment } & \multicolumn{3}{|c|}{ After 21 days treatment } \\
\hline & $10 \mathrm{C}$ & $16 \mathrm{C}$ & $22 \mathrm{C}$ & $\overline{10 C}$ & $16 \mathrm{C}$ & $22 \mathrm{C}$ \\
\hline $\begin{array}{l}\text { None } \\
\mathrm{GA}_{3} \\
\mathrm{PBZ} \\
\mathrm{GA}_{3}+\mathrm{PBZ}\end{array}$ & $\begin{array}{l}44 \mathrm{c}^{2} \\
76 \mathrm{a} \\
25 \mathrm{~d} \\
61 \mathrm{~b}\end{array}$ & $\begin{array}{r}70 \mathrm{~b} \\
100 \mathrm{a} \\
36 \mathrm{c} \\
70 \mathrm{~b}\end{array}$ & $\begin{array}{l}77 \mathrm{ab} \\
89 \mathrm{a} \\
22 \mathrm{c} \\
68 \mathrm{~b}\end{array}$ & $\begin{array}{l}46 \mathrm{~b} \\
70 \mathrm{a} \\
31 \mathrm{~b} \\
61 \mathrm{a}\end{array}$ & $\begin{array}{l}84 \mathrm{a} \\
89 \mathrm{a} \\
32 \mathrm{~b} \\
93 \mathrm{a}\end{array}$ & $\begin{array}{r}105 \mathrm{a} \\
92 \mathrm{ab} \\
21 \mathrm{c} \\
83 \mathrm{~b}\end{array}$ \\
\hline $\begin{array}{l}\text { RZT linear } \\
\text { RZT quadratic } \\
\text { PGR } \times \text { RZT }\end{array}$ & & $\begin{array}{l}\text { NS } \\
\text { NS } \\
*\end{array}$ & & & $\begin{array}{c}* * \\
* \\
* *\end{array}$ & \\
\hline
\end{tabular}

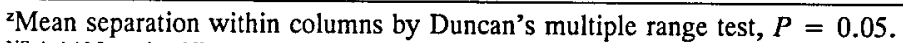

NS,*,**Not significant or significant at $P=0.05$ or 0.01 , respectively.

Table 4. Effects of root-zone temperature (RZT) and plant growth regulator (PGR) treatments on root and shoot dry weight per plant (Expt. 2).

\begin{tabular}{|c|c|c|c|c|c|c|c|c|c|}
\hline \multirow[b]{2}{*}{ PGR } & \multicolumn{3}{|c|}{ Shoot wt (mg) } & \multicolumn{3}{|c|}{ Root wt (mg) } & \multicolumn{3}{|c|}{ Shoot : root dry wt ratio } \\
\hline & $10 \mathrm{C}$ & $16 \mathrm{C}$ & $22 \mathrm{C}$ & $10 \mathrm{C}$ & $16 \mathrm{C}$ & $22 \mathrm{C}$ & $10 \mathrm{C}$ & $16 \mathrm{C}$ & $22 \mathrm{C}$ \\
\hline None & $590 b^{x}$ & 1790 a & $2260 a$ & $190 \mathrm{a}$ & $380 \mathrm{a}$ & $460 \mathrm{a}$ & $3.1 \mathrm{~b}$ & $4.7 \mathrm{c}$ & 4.9 \\
\hline $\mathrm{GA}_{3}$ & $780 \mathrm{a}$ & $1480 \mathrm{ab}$ & 2070 a & $120 \mathrm{~b}$ & $190 \mathrm{~b}$ & $280 \mathrm{~b}$ & $6.5 \mathrm{a}$ & $7.8 \mathrm{a}$ & $7.4 \mathrm{a}$ \\
\hline PBZ & $500 \mathrm{~b}$ & $1110 \mathrm{~b}$ & $1070 \mathrm{c}$ & $160 a b$ & $370 \mathrm{a}$ & $410 \mathrm{a}$ & $3.1 \mathrm{~b}$ & $3.0 \mathrm{~d}$ & $2.6 \mathrm{c}$ \\
\hline $\mathrm{GA}_{3}+\mathrm{PBZ}$ & $750 \mathrm{a}$ & $1560 \mathrm{a}$ & $1450 \mathrm{~b}$ & $130 \mathrm{~b}$ & $250 \mathrm{~b}$ & $190 \mathrm{~b}$ & $5.8 \mathrm{a}$ & $6.2 \mathrm{~b}$ & $7.6 \mathrm{a}$ \\
\hline $\begin{array}{l}\text { RZT linear } \\
\text { RZT guadratic }\end{array}$ & & NS & & & $* *$ & & & 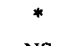 & \\
\hline $\begin{array}{l}\text { RZT quadratic } \\
\text { PGR } \times \mathrm{RZT}\end{array}$ & & NS & & & NS & & & NS & \\
\hline PGR $\times \mathrm{RZT}$ & & **** & & & NS & & & NS & \\
\hline
\end{tabular}

${ }^{2}$ Mean separation within columns by Duncan's multiple range test, $P=0.05$.

NS,*,*****Not significant or significant at $P=0.05,0.01$, or 0.001 , respectively.

For root surface area, the binary image of the root system was formed by totalling all pixels with a gray level equal to or higher than that of the finest root. The percentage of the $512 \times 480$ pixel frame occupied by the root system was highly correlated $(r=$ 0.95 ) to root surface area, determined by multiplying root length (estimated by the line intersect method) by average root diameter (determined by ocular micrometer) and $\pi$. For estimating mean root diameter, the average gray intensity of each digital image was normalized by referring it to the root surface area. The normalized intensity of a greater shoot elongation and root volume than 8C (Expt. 1, Table 1). Each PGR also influenced these growth and development indicators but the magnitude of the effect appeared to depend on RZT. With regard to shoot elongation, $\mathrm{GA}_{3}$ and $\mathrm{GA}_{3}+\mathrm{PBZ}$ stimulated growth relative to $\mathrm{PBZ}$ alone at $8 \mathrm{C}$ but not at $24 \mathrm{C}$, even though PBZ clearly inhibited shoot growth at the higher RZT (Table 1). Final root volume was reduced by both GA and PBZ at $8 \mathrm{C}$, but only $\mathrm{GA}_{3}$ was inhibitory at $24 \mathrm{C}$.

Shoot and root dry weights, the ratio of shoot dry weight to root dry weight, final root volume, and total root surface area all increased in a linear manner with increasing RZT (Expt. 2, Table 2). However, across all PGR treatments, neither final shoot length (Table 2) nor mean root diameter (data not shown) were influenced by RZT.

The indication from Expt. 1 that $\mathrm{GA}_{3}$ in the medium stimulates shoot elongation most effectively at a low RZT was confirmed by the results of Expt. 2 (Table 3). A significant degree of $\mathrm{GA}_{3}$ enhancement of shoot elongation of the 10C RZT trees was evident within 14 days, and this effect continued to the end of the experiment at 21 days. This enhancement was clearly related to greater internode elongation (data not shown), but $\mathrm{GA}_{3}$ also increased shoot dry weight at the lowest RZT (Table 4). GA promotion of shoot elongation was also observed at $16 \mathrm{C}$ 2 weeks after the first application but not at $22 \mathrm{C}$.

The suppression of shoot elongation by PBZ was also evident by the 2nd week after the introduction of the chemical and persisted through the experiment (Table 3). With this PGR, relative growth suppression was greater at the higher RZTs. Total dry weight increase of the shoot was suppressed by PBZ at 16 and $22 \mathrm{C}$ but not at $10 \mathrm{C}$ (Table 4).

The addition of $\mathrm{GA}_{3}$ resulted in a clear reversal of the PBZ suppression of shoot elongation growth at all RZTs (Table 3). Likewise, the addition of $\mathrm{GA}_{3}$ resulted in shoot dry weight values greater than PBZ alone at all RZTs (Table 4).

With regard to the PGR effects on roots in Expt. 2, $\mathrm{GA}_{3}$ and $\mathrm{GA}_{3}+\mathrm{PBZ}$ reduced root dry weight and root volume at all RZTs (Tables 4 and 5) and reduced root surface area at 16 and 22C RZT (Table 5). PBZ alone increased root volume at $22 \mathrm{C}$, and mean root diameters $(\mathrm{mm})$ across all RZTs were: control, 0.94a; $\mathrm{GA}_{3}, 0.90 \mathrm{a}$; PBZ, 1.13b; and $\mathrm{GA}_{3}+\mathrm{PBZ}$, 0.87a, with mean separation (Duncan's multiple range test) applied at $P$ $=0.05$. However, relative to the control plants, PBZ failed to increase root dry weight at any RZT.

The results of these two brief experiments show that root-zone temperature can have an important influence on whole-plant growth and development and on the responsiveness of peach seedlings to root-applied growth regulators. Low RZT (8 or 10C in this study) inhibited shoot elongation and shoot dry weight accumulation, and these effects were at least partially counteracted by nutrient solution $\mathrm{GA}_{3}$ renewed each week. The $\mathrm{GA}_{3}$ 
Table 5. Effects of root-zone temperature (RZT) and plant growth regulator (PGR) treatments on roo volume and root surface area of peach seedlings at the termination of Expt. 2.

\begin{tabular}{lccccccc}
\hline \hline & \multicolumn{3}{c}{ Root vol $(\mathrm{ml})$} & & \multicolumn{3}{c}{ Root surface area $\left(\mathrm{cm}^{2}\right)$} \\
\cline { 2 - 4 } \cline { 6 - 8 } PGR & $10 \mathrm{C}$ & $16 \mathrm{C}$ & $22 \mathrm{C}$ & & $10 \mathrm{C}$ & $16 \mathrm{C}$ & $22 \mathrm{C}$ \\
\hline None & $2.1 \mathrm{a}^{2}$ & $4.7 \mathrm{a}$ & $4.7 \mathrm{~b}$ & & $157 \mathrm{a}$ & $300 \mathrm{a}$ & $330 \mathrm{a}$ \\
GA $_{3}$ & $1.3 \mathrm{~b}$ & $1.5 \mathrm{~b}$ & $2.2 \mathrm{c}$ & & $141 \mathrm{a}$ & $164 \mathrm{~b}$ & $194 \mathrm{~b}$ \\
PBZ & $2.2 \mathrm{a}$ & $5.8 \mathrm{a}$ & $6.3 \mathrm{a}$ & & $146 \mathrm{a}$ & $285 \mathrm{a}$ & $362 \mathrm{a}$ \\
$\mathrm{GA}_{3}+$ PBZ & $1.1 \mathrm{~b}$ & $1.7 \mathrm{~b}$ & $1.7 \mathrm{c}$ & & $138 \mathrm{a}$ & $192 \mathrm{~b}$ & $174 \mathrm{~b}$ \\
RZT linear & & $*$ & & & $* *$ & $*$ & \\
RZT quadratic & & NS & & & & $* *$ & \\
PGR $\times$ RZT & & $* *$ & & &
\end{tabular}

Mean separation within columns by Duncan's multiple range test, $P=0.05$.

Not significant or significant at $P=0.05$ or 0.01 , respectively.

effects on shoot growth, relative to the control plants, declined at the higher RZTs. However, at all root temperatures, $\mathrm{GA}_{3}$ effectively reversed the suppressing effect of PBZ on shoot elongation.

It is also evident from these results that the growth regulators in the root medium had profound effects on the distribution of the dry weight increase of peach seedlings (Table 4). $\mathrm{GA}_{3}$ increased the proportion of total dry weight directed to the shoot, whereas PBZ had the opposite effect. Furthermore, while the interaction with RZT was not statistically significant, $\mathrm{GA}_{3}$-treated plants appeared to direct relatively more dry weight to the shoot as root temperature increased.

Perhaps the most likely explanation for the decline, relative to the control plants, of the shoot growth response to nutrient solution $\mathrm{GA}_{3}$ at higher RZTs is that the root system becomes capable of producing and transporting enough native gibberellin (GA) to saturate the shoot growth requirement. This RZT/GA interaction and the fact that rootapplied $\mathrm{GA}_{3}$ countered the PBZ-induced shoot growth retardation at all RZTs certainly suggests a role for the roots in peach seedling GA metabolism. However, the concomitant suppression of root development by $\mathrm{GA}_{3}$, evident at all RZTs, indicates that if roots do produce and transport a native GA required for shoot development (see Graebe and Ropers, 1978; Sponsel, 1983; and Torrey, 1976 for discussions of the plausibility of this suggestion), they can fulfill this role even while experiencing serious growth inhibition by the exogenous $\mathrm{GA}_{3}$.

Other pomologists have shown that foliar sprays and root-zone treatments with PBZ effectively suppress shoot growth of peach (Early and Martin, 1988; Erez, 1986; Williamson et al., 1986), and Casper and Taylor
(1989) report that foliar-applied $\mathrm{GA}_{3}$ will reverse the growth suppression caused by PBZ. Our results contribute to this body of knowledge by showing that: a) $\mathrm{GA}_{3}$ can be introduced to peach trees via the root system; b) very low concentrations of PBZ (1 to $2 \mathrm{ppb}$ ) suppress shoot growth when applied via the nutrient solution (confirming a result previously reported by Early and Martin, 1988), but this effect is reversible across a range of RZTs by root-applied $\mathrm{GA}_{3}$; and c) PBZ applied to the roots increases average root diameter, and even root volume at higher RZTs, but may not increase root dry weight relative to untreated plants. It is also evident that root-applied $\mathrm{GA}_{3}$ and $\mathrm{PBZ}$ influence wholeplant dry weight distribution in opposite ways, a feature that may prove important in commercial horticulture.

In horticultural practice, foliar or root-applied $\mathrm{GA}_{3}$ may prove useful for reversing the effects of a previous PBZ treatment or for promoting early season shoot growth of peach trees when root-zone temperature is low enough to limit shoot growth and development. The extent to which pulse treatments of $\mathrm{GA}_{3}$ will promote shoot growth without serious or long-lasting suppression of root growth should be the subject for further investigation. Similarly, PBZ or one of the several related chemicals may prove to be beneficial for reducing shoot : root ratios of planting stock produced under conditions of at leastmoderately high root-zone temperatures.

\section{Literature Cited}

Anderson, S.J., W.M. Jarrell, and E. Franco-Vizcaino. 1988. Effects of concentration and treatment duration upon dwarf pea response to gibberellic acid root treatments in solution culture. Plant \& Soil 112:279-287.
Arteca, R.N., E.J. Holcomb, C. Schlagnhaufer, and D.-S. Tsai. 1985. Effects of root applications of gibberellic acid on photosynthesis, transpiration and growth of geranium plants. HortScience 20:925-927.

Casper, J.A. and B.H. Taylor. 1989. Growth and development of young 'Loring' peach trees after foliar sprays of paclobutrazol and $\mathrm{GA}_{3}$. HortScience 24:240-242.

Davies, L.J. and L. Rappaport. 1975. Metabolism of tritiated gibberellins in $d-5$ dwarf maize. I. In excised tissues and intact dwarf and normal plants. Plant Physiol. 55:620-625.

Early, J.D., Jr., and G.C. Martin. 1988. Sensitivity of peach seedling vegetative growth to paclobutrazol. J. Amer. Soc. Hort. Sci. 113:2327.

Erez, A. 1986. Effect of soil applied paclobutrazol in drip-irrigated peach orchards. Acta Hort. 179:513-520.

Graebe, J.E. and H.J. Ropers. 1978. Gibberellins, p. 107-204. In: D.S. Letham, P.B. Goodwin, and T.J.V. Higgins (eds.). Phytohormones and related compounds: A comprehensive treatise. vol. 1. Elsevier/North Holland, Amsterdam.

Heidmann, L.J. 1982. Effect of selected natural and synthetic growth regulators on the growth of Ponderosa pine seedlings. Forest Sci. 28:156 160.

Hewitt, E.J. 1966. Sand and water culture methods used in the study of plant nutrition. Tech. Comm. 22. Commonwealth Bureau of Horticulture and Plantation Crops, East Mailing, Maidstone, Kent, U.K.

Jackson, D.I. and R.J. Field. 1972. Light and hormone interaction in apical dominance in Phaseolus vulgaris L. Arm. Bot. 36:525-532.

Lavender, D.P., G.B. Sweet, J.B. Zaerr, and R.K. Hermann. 1973. Spring shoot growth in Douglas-fir may be initiated by gibberellins exported from the roots. Science 182:838-839.

Little, C.H.A. and K. Loach. 1975. Effect of gibberellic acid on growth and photosynthesis in Abies balsamea. Can. J. Bot. 53:1805-1810.

Menhenett, R. and P.F. Waring. 1975. Possible involvement of growth substances in the response of tomato plants (Lycopersicon esculentum Mill.) to different soil temperatures. J. Hort. Sci. 50:381-397.

Sponsel, V. 1983. In vivo gibberellin metabolism in higher plants, p. 15 1-250. In: A. Crozier (ed.). The biochemistry and physiology of gibberellins. Praeger, New York.

Tattini, M., P. Mariotti, L. Tazzari, and V. Carmi. 1988. Artificial substrates, liquid fertilization and apple culture. Results in model and amount of growth. Acta Hort. 221:229-234.

Torrey, J.G. 1976. Root hormones and plant growth. Annu. Rev. Plant Physiol. 27:435-459.

Williamson, J.G., D.C. Coston, and L.W. Grimes. 1986. Growth responses of peach roots and shoots to soil and foliar-applied paclobutrazol. HortScience 21:1001-1003. 